\title{
DO IMMIGRANTS DISRUPT THE INTERNATIONAL ORDER?
}

\author{
Imigrantes perturbam a ordem internacional?
}

Patrícia Nabuco Martuscelli*

International order is a critical concept for international relations. In his seminal work "The Anarchical Society: A Study of Order in World Politics", Hedley Bull (2012) argues that order means that things are related following a type of pattern. The international order can be defined as the way international actors relate to each other following a specific pattern. A traditional view of international relations may understand that only States are part of the international order. However, especially in the last 20 years, other actors have been recognized as part of the international order like International Organizations, transnational companies, non-governmental organizations (NGOs), and even individuals. If we consider that individuals are part of the international order, we can also ask if those individuals can disrupt the international order. Among different groups of individuals, we can put attention on immigrants or people that are born in one country and live in another country because of many reasons, including searching for better conditions of life, fleeing from persecutions, armed conflicts, human rights violations, and natural disasters among others. According to data from the World Migration Report 2020, there were 272 million immigrants or $3.5 \%$ of the world population in 2019. This essay discusses if immigrants can disrupt the international order how we know it. Initially, it discusses how the international order we know was formed. Secondly, it presents why $3.5 \%$ of the world population may be seen as a threat to the States and the international order. Thirdly, it presents some ideas on how immigrants and refugees connect to the idea of international order. The final part of the essay answers the title question. It presents what the international order could be if we consider that immigrants are an inherited part of the international order.

The beginning of the international order, as we know, dates to 1648 with the Peace of Westphalia and the creation of the idea of sovereignty. At that time, States were recognized as the traditional actors of international relations that had internal sovereignty and external sovereignty. The idea of internal sovereignty

\footnotetext{
Doutora em Ciência Política pela Universidade de São Paulo. São Paulo, Brasil. E-mail: patnabuco@alumni.usp.br. Orcid: 0000-0003-2611-2513.
} 
means that the State can rule in its territory without the interference of another State. In order to do that, a State needs to know what constitutes its territory and for whom this State is responsible. The concept of borders was then put in practice because it was a requirement to exercise internal sovereignty. The idea of external sovereignty understands that a State can deal with other States in the international arena and that no State will rule the other actors, or interfere in its internal businesses. That means states are independent and autonomous in the international arena. Sovereignty is the core principle of the international order. However, the way the international order was organized changed since them. Initially, we had an international order that was ruled by many States with the same amount of power constituting what we can call a multipolar order. We should understand that this anarchical order, with no State to rule the others, does not mean a lack of rules. The States, respecting the idea of sovereignty, used different techniques to keep the order: agreements, negotiations, and even conflict. The Russian Revolution in 1917 and the end of the First World War (1914-1918) created a scenario (that was concluded with the end of the Second World War in 1945) with a bipolar order with two States that were more powerful than the others: the Union of the Socialist Soviet Republics (USSR) and the United States of America (USA). Even with two powerful States, other States continued to enjoy their internal and external sovereignty.

After the Second World War (1939-1945), the United States created international organizations where States could negotiate and follow their rules like the United Nations, the World Bank, and the International Monetary Fund. This period marks a time in the international order where States waived part of their sovereignty to create international bodies that would influence in the international decision-making process. The end of the Second World War also marks the emergence of the individual as an international actor. The Universal Declaration of Human Rights (1948) affirmed that all human beings had rights that should be respected and guaranteed by the States. The idea of internal sovereignty was not limitless anymore. States' sovereignty was limited by the human rights of individuals and by negotiations in international fora. The end of the Cold War (1947-1991) and the dissolution of the USSR marked a new chapter in the international order. While some analysts argued that the USA was the only power after the Cold War, others affirmed that there was a situation of multipolarity with many important actors like the USA, the European Union, and Japan. Nowadays, there is a fair understanding that we have a situation of multipolarity with some actors with more power like the USA, the European Union, Russia, and China. Two things were constant in this brief history of the international order: sovereign states and the international order.

Although we can argue that the international order was changing since 1648 , its central core idea of sovereignty remained. Therefore, we cannot say 
that any of those events disrupted the international order. It changed and adapted to new events. In this logic, if two world wars could not disrupt the international order, why do we think that immigrants (simple human beings) can disrupt the order? To answer this question, we need to understand what immigration means. Migration is a natural thing for animals. Many species cross international borders daily or seasonally because of many factors, including procreation, dispute for territory, and others. The human species is one of those animals that migrate. The spread of our species was due to this natural will to move. We can find humans living on all continents because our species migrated.

At that time, there were no borders. The idea of the border came with the concept of sovereignty. Until them, people were freely able to move. Nevertheless, since long before, States influenced people's migration. Between the 16th and the 19th centuries, States were involved in the slavery trade. Their nationals captured people in one country and sent them to other countries with the consent of the State and against the will of slaved people. With the end of slavery and the need for labor, some States created policies to bring immigrants to work in their lands. Those policies motivated millions of Europeans to go to the Americas in the 19th and 20th centuries. The United States of America, Brazil, and Argentina, among others, are countries constructed by immigration.

Those millions of people leaving Europe and going to the American continent were not considered to be disruptive of the international other. They contributed to form the culture and society of those countries. They helped those countries to develop and grow. In a way, they fomented the international order guaranteeing peace in countries with more people than they could provide for by finding other opportunities to those people that were looking for a better life across the Atlantic Ocean. If this is the same thing that people in Latin America, Asia, Africa, and European countries outside the European Union are doing today, why do immigrants appear in political discourses as a disruptive threat to the international order now? Because States perceived that those immigrants are violating their sovereignty, i.e., they do not follow the state rules. Different from American countries, many receiving countries do not adopt policies to motivate migrations. Although many studies show that immigrants contribute to the local economy and that countries that have a growing elderly population will need immigrants to sustain their economies, politicians adopt a discourse that those immigrants are a problem. The political discourse of many receiving countries blames immigrants for internal problems like unemployment, economic crisis, poor public services, rise in criminality, terrorism. For politicians, it is easier to blame immigrants for internal problems because they are "different" from the nationals. They represent the unknown, the "Other". They can take the blame for internal problems that were also a decision of national politicians and societies. 
Although the idea of border is older than that, increased control of people's movement between borders started at the end of the XIX century. In the USA, legislation controlling the migration of one nationality (the Chinese) dated from 1882. Our complex visa system developed in the 1930s. Migration became the synonym of states exercising their sovereign right to decide who should enter and stay in their territories. One example of that was the creation of the juridical concept of asylum. In 1951, States agreed the United Nations Convention on the Refugee Status that defines a refugee as a person who has left her country of origin or habitual residence due to a well-founded fear of persecution because of her race, religion, nationality, political opinions or because she belongs to a particular social group. States decided to grant protection to nationals from other countries who were being persecuted since they were already in their territories. That means States never gave up their sovereign right to control their borders. If we review human rights treaties, we see clearly that States never recognized people's right to enter a State if she is not a national of it. Hence, individuals have a clear right to leave their states and to seek asylum, but they are not allowed to enter a state against this State's will.

We see that States loosen up their borders to goods, investments, and companies. By the other, they tighten their control of people. Migration control became the synonym of avoiding terrorism, global diseases, and "bad people." After the terrorist attacks of September 11, 2001, countries adopted more robust measures to control who is entering their borders. At the same time, we saw the start of new armed conflicts and environmental tragedies in the last 15 years. According to the United Nations High Commissioner for Refugees (UNHCR), in 2019, there 79.5 million people that were forcibly displaced from their houses, including 26 million refugees, 3.6 Venezuelans displaced abroad, and 4.2 million asylum-seekers. That is the highest number ever recorded. Eighty-five percent of them are in developing countries. We have a situation where more people are trying to leave their countries than States willing to receive them. The result is a rise in the number of walls in the world and deaths on the borders and at sea.

Europe is a compelling practical case to analyze if immigrants disrupt the order. In 1999, the Schengen Agreement and Convention became part of the European Union legal framework. This agreement accepted by 22 of the 28 members and Norway, Iceland, Switzerland, and Lichtenstein guarantees the free and unrestricted movement of people from those countries in their territories. European countries were able to give up part of their sovereignty to grant their citizens the possibility to live, travel, and work in more than 20 different countries. The counterpart was the creation of a common asylum and immigration policies for people outside the Schengen space. The Europeans immigrating inside the Schengen space did not disrupt the European order. 
They were perceived as a living example of the benefits of regional integration and the construction of a united Europe. In 2015, people fleeing conflicts and looking for better living conditions started to enter more in European countries by sea and on foot. Those immigrants were treated as an "immigrant crisis" that showed the flaws of the European common asylum system. Those immigrants were used in nationalist discourses that influenced decisions like the United Kingdom's exit from the European Union in 2016. Immigrants became a disruption in the European order, not because of immigration per se, but because of the way immigration was used as a synonym of sovereignty in political and mediatic discourses.

Someone could argue that immigration that is not controlled by States represents a breach in the traditional idea of sovereignty. In that sense, immigrants could disrupt the international order centered only on a traditional idea of sovereignty. However, Bull's (2012) definition of international order involves a pattern of activity among international actors to guarantee the primary objectives of the society of states that are the preservation of the values of security, property, and agreements; the preservation of the system of the State with the independence of the sovereign units, and the preservation of peace. If we consider this definition of international order and how the international order was changing in the last 370 years, saving the lives of immigrants is necessary to preserve the order because that is the only way to guarantee security and peace. Since immigrants are not a direct threat to states' independence and other people's properties, they do not disrupt the international order. On the contrary, when States create policies that let people die at the borders (and at sea), they are disrupting the international order because they are not keeping their promises (human rights treaties). They are creating a more insecure world for human beings that want to migrate.

Mervyn Frost (2003), in his essay "Thinking ethically about refugees: A case for the transformation of global governance". defends that States should receive refugees because of two arguments. The first one is that all human beings are part of the "global civil society" that grants them rights, especially the right to life. If somebody is having this right violated, this means that all human beings that are part of the "global civil society" are having a right violated. Therefore, States should let people in because they are human beings that are suffering. When states do not help immigrants, they are violating their most basic human right to life. The second argument is that all people are citizens of a State that, in theory, should protect them. Hence, people are part of a "global society of democratic and democratizing states". In this society, a State is recognized by other states as a sovereign state if it is protecting its people. If this State harms its people or it cannot protect them, this puts the entire global society of democratic and democratizing states in danger. In that case, 
to protect the "global society of democratic and democratizing states", a State should let other nationals that were suffering in other states to let in and live in its territory until this person can return to her place of origin. That means, what are the whole idea of having sovereignty states if they are not preserving people's lives? Therefore, other States should grant protection to those people in need as a form to justify the existence of this "global society of democratic and democratizing states".

This ethical argument may be easier justifiable for people fleeing wars and torture. However, it is extendable to people searching for better living conditions and fleeing natural and climatic disasters. If States cannot protect people and are letting people die, States are not necessary anymore. Moreover, the whole idea of sovereignty is useless. In that sense, immigrants are not the ones disrupting the international other, but the States that are letting immigrants die in their borders and at the sea are the disruptive force of the international order. Following this argument, we could think that the international order needs to adapt to the concept of sovereignty as it has been adapting to many configurations of power in the last 370 years. Immigration is no violation of state sovereignty. If we consider that immigration is a natural phenomenon that many animal species, including human beings, engage in, States should manage migration in a way to let people in, like the example of the Schengen space. In we consider the situation in Europe, nobody would argue that Germany, Switzerland, or France are not sovereign countries because they let other Europeans enter their territory freely and work there. Nobody would argue that this arrangement disrupted the European order. On the contrary, many argue that the Schengen area was crucial to construct a European identity. As a consequence, nobody should argue that immigrants disrupt the international order.

\section{References}

BULL, Hedley. The anarchical society: a study of order in world politics. London: Macmillan International Higher Education, 2012.

FROST, Mervin. Thinking ethically about refugees: A case for the transformation of global governance. In: NEWMAN, Edward and VAN SELM, Joanne (eds). Refugees and forced displacement: International security, human vulnerability, and the State. New York: United Nations University Press, 2003, p. 109-129.

INTERNATIONAL ORGANIZATION FOR MIGRATION (IOM). World Migration Report 2020. Geneva: International Organization for Migration, 2019. Available at: <https://publications.iom.int/system/files/pdf/wmr_2020.pdf>. Accessed: 05.07.2020.

UNITED NATIONS HIGH COMMISSIONER FOR REFUGEES (UNHCR). Global Trends: Forced Displacement in 2019. Geneva: United Nations High Commissioner for Refugees, 2020. Available at: <https://www.unhcr.org/5ee200e37.pdf>. Accessed: 05.07.2020. 